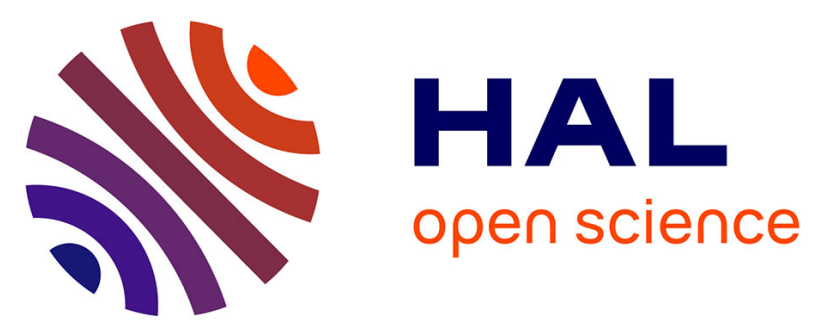

\title{
Persistent Organic Pollutants in a marine bivalve on the Marennes-Oléron Bay and the Gironde Estuary (French Atlantic coast) -Part 2: Potential biological effects
} Andrea Luna Acosta, Paco Bustamante, Hélène Budzinski, Valérie Huet, Hélène Thomas-Guyon

\section{To cite this version:}

Andrea Luna Acosta, Paco Bustamante, Hélène Budzinski, Valérie Huet, Hélène Thomas-Guyon. Persistent Organic Pollutants in a marine bivalve on the Marennes-Oléron Bay and the Gironde Estuary (French Atlantic coast) -Part 2: Potential biological effects. Science of the Total Environment, 2014, 514, pp.511-522. hal-01223660

\section{HAL Id: hal-01223660 \\ https://hal.science/hal-01223660}

Submitted on 3 Nov 2015

HAL is a multi-disciplinary open access archive for the deposit and dissemination of scientific research documents, whether they are published or not. The documents may come from teaching and research institutions in France or abroad, or from public or private research centers.
L'archive ouverte pluridisciplinaire HAL, est destinée au dépôt et à la diffusion de documents scientifiques de niveau recherche, publiés ou non, émanant des établissements d'enseignement et de recherche français ou étrangers, des laboratoires publics ou privés. 


\section{Persistent Organic Pollutants in a marine bivalve on the Marennes-Oléron}

Bay and the Gironde Estuary (French Atlantic coast) - Part 2: Potential biological effects

Luna-Acosta, A. ${ }^{1,4}$, Bustamante, P. $^{1}$, Budzinski, H. ${ }^{2,3}$, Huet $\mathrm{V}^{1}$, Thomas-Guyon, ${ }^{1}{ }^{1}$

${ }^{1}$ Littoral Environnement and Sociétés (LIENSs), UMR 7266 CNRS-Université de La Rochelle, 2 rue Olympe de Gouges - F-17042 the Rochelle Cedex 01, France

${ }^{2}$ Université Bordeaux 1, Laboratoire de Physico-ToxicoChimie de l'environnement (LPTC), UMR EPOC (UMR5805 CNRS-Université de Bordeaux 1), 351 Cours de the Libération, 33405 Talence, France

${ }^{3}$ CNRS, Laboratoire de Physico-ToxicoChimie de l'environnement (LPTC), EPOC (UMR 5805, CNRS-Université de Bordeaux 1), 351 Cours de the Libération, 33405 Talence, France

${ }^{4}$ Present address: Departamento de Ecología y Territorio, Universidad Javeriana, Transv. 4 No. 42-00, Bogotá, Colombia

* Corresponding authors: A. Luna-Acosta

Departamento de Ecología y Territorio

Universidad Javeriana

Transv. 4 No. 42-00

Bogotá, Colombia

Email: aluna1508@yahoo.com

Tel: +5713208320 Ext. 4824

Fax: +571 3208320 Ext. 4847 
Abstract: Contaminant effects on defence responses of ecologically and economically important organisms, such as the Pacific oyster Crassostrea gigas, are likely to influence their ability to resist infectious diseases, particularly at the young stages. The aim of this study was to explore the potential relationships between organic contaminants accumulated in the soft tissues of juvenile oysters, defence responses and physiological condition. Oysters were transplanted during summer and winter periods in different sites in the Marennes-Oléron Bay, the first area of oyster production in France, and in the Gironde Estuary, the biggest estuary in Occidental Europe. Among the battery of biochemical and physiological biomarkers applied in the present work (superoxide dismutase -SOD-, catalase, glutathione peroxidase -GPx-, malondyaldehyde -MDA-, catecholase, laccase and lysozyme in gills, digestive gland, mantle and haemolymph, glycogen, proteins and lipids in the digestive gland and the condition index at the whole organism level), MDA and lysozyme in the digestive gland and SOD, GPx and laccase in plasma contibuted to significantly discriminate sites in which oysters bioaccumulated different levels of heavy polycyclic aromatic hydrocarbons (HPAHs), polychlorobiphenyls (PCBs), polybromodiphenylethers (PBDEs), dichlorodiphenyltrichloroethanes (DDTs) and lindane. These results strengthen the hypothesis that it is possible to differentiate sites depending on their contamination levels and biological effects by carrying out studies with transplanted juvenile oysters. In addition, correlations between antioxidant and immune defence responses and PAH and DDT body burdens in the first area of oyster production in France, the Marennes-Oléron Bay, and where massive oyster mortalities have been reported, suggest that the presence of organic chemical contaminants in the Marennes-Oléron Bay may influence defence responses in juveniles of $C$. gigas, and, therefore, could influence their ability to resist infectious diseases.

Key words: Crassostrea gigas - Oxidative stress - Immune humoral defences - Polycyclic aromatic hydrocarbons - Persistent Organic Pollutants - Active biomonitoring 


\section{Introduction}

The Pacific oyster, Crassostrea gigas (Thunberg 1753), is the leading aquaculture product at the worldwide level (FAO 2010), and is considered an important species for ecosystem functioning (Gutierrez et al. 2003). Hence, the maintenance of healthy populations of this economically and ecologically important organism is of considerable relevance.

Like other bivalves, $C$. gigas has been extensively used in environmental risk assessment as pollutant concentrations in its tissues faithfully reflect the environmental concentrations (Ref). This sessile filter-feeder bivalve mollusc bioaccumulates contaminants in its tissues (e.g. Auffret et al. 2004, Livingstone 1993), especially in areas with intense human activities, frequently contaminated with chemical compounds. Survey networks such as ROCCH (Réseau d'Observation de Contamination Chimique du Littoral, previously RNO, in France) have implemented monitoring programs known as Mussel Watch Programs (MWPs), using naturally settled populations of marine bivalves, such as C. gigas, as sentinel species for inorganic and organic contamination and have shown to contribute to the improvement of water quality in countries such as the USA (Melwani 2013). However, this type of monitoring possess no experimental control and cannot be used to evaluate short-term trends in contaminants distribution. Another type of survey, called active biomonitoring, consists on using caged bivalves transplanted to sites with different levels of contamination. The main advantages of active biomonitoring over traditional MWPs is 1) the experimental control, which is achieved using bivalves of similar genetic and environmental stocks at all test sites, pre-selecting test animal size or age group, and monitoring animals during the test, and 2) the possibility to examine both short- and long-term trends in contaminants distribution and related effects (Besse et al. 2012, Galgani et al. 2011, Gunther et al. 1999). Both types of monitoring analyze chemical body burdens in marine bivalves. In addition to chemical analyses, the use of biological markers or biomarkers, have been introduced in some monitoring programs since chemical analyses do not offer by themselves any type of indication of possible deleterious effects of 
contaminants on marine organisms (Allan et al. 2006, Cajaraville et al. 2000). Biomarker responses (i.e. biochemical, cellular, physiological, behavioural or energetic responses of the organisms) on body fluids, cells, tissues, or on whole animals are considered as early-warning sensitive signals of deleterious effects of contaminants since they can be used to evaluate the exposure to and toxic effects of contaminants (Bodin et al. 2004, Livingstone 1993, Magni et al. 2006; Ross et al. 2002), especially if several biomarkers are measured at the same time in the same animals (Lagadic et al. 1994).

Among biomarker responses, defence mechanisms may affected by the presence of contaminants in the environment (Lacoste et al. 2001, Perdue et al. 1981). Enzymes such as superoxide dismutase (SOD; EC 1.15.1.1), catalase (CAT; EC 1.11.1.6) and glutathione peroxidase (GPx; EC 1.11.1.9) regulate the presence of reactive oxygen species (ROS) in the organism (Neumann et al. 2001), and when ROS overwhelm these antioxidant enzyme activities, this may lead to the lipid peroxidation of polyunsaturated fatty acids, resulting in the formation of reactive electrophile species, such as malondialdehyde (MDA), considered as a marker for oxidative stress (Gerard-Monnier et al. 1998). Humoral immune defences in bivalves, key enzymes such as phenoloxidase (PO, EC 1.14.18.1) and lysozyme (EC 3.2.1.17) participate in the inactivation of invading pathogens (Hagger et al. 2005, Söderhäll \& Cerenius 1998), and therefore a depletion of these enzymes could influence the ability of the organism to resist infectious diseases.

Lagadic et al. (1994) suggests that energy reserves could also be considered as biomarkers reflecting sublethal changes from a stressful xenobiotic exposure. Among energy reserves in Ostreidae, the digestive gland is the main reserve organ of glycogen (Gabbott \& Head 1980) and an important organ of reserve of lipids (De La Parra et al. 2005), especially when glycogen reserves are depleted (Beninger \& Lucas, 1984). Glycogen reserves in the digestive gland are generally used in the synthesis of lipids and/or proteins for gametogenesis (De La Parra et al. 2005, Gabbott 1975). Glycogen, protein and/or lipid reserves may be also depleted in the presence of contaminants (Pellerin-Massicotte et al. 1994). The condition index is often used as index endpoint, i.e. to evaluate bivalve condition and is considered as one 
of the best indicators of gross body state for environmental studies and thus, could also reflect sublethal changes from a stressful xenobiotic exposure (Hyötylänen et al. 2002).

Previous studies in juveniles of $C$. gigas have shown that the responses of biomarkers such as SOD, CAT, GPx, MDA, catecholase, laccase and lysozyme can be modulated in experiments carried out in laboratory-controlled conditions with organic contaminants and that these responses are tissuedependent (Luna-Acosta et al. 2011a, 2012). However, although laboratory studies may help to identify biomarkers of interest, a lack of validation may occur when using these biomarkers in the field with organisms from contaminated and reference sites, e.g. body size and/or gross body state (which can be estimated through flesh dry weight, shell dry weight or condition index) may influence biomarker responses (Packard \& Boardman 1999), and biomarker responses may vary depending on environmental factors, such as seawater temperature (Oliver and Fisher 1995). To date, no transplantation studies with juvenile Pacific oysters analysing biomarker responses have been carried out to our knowledge, despite the fact that massive summer mortalities, particularly of juveniles of $C$. gigas, have become a widespread concern in the world in recent decades (Cheney et al. 2000, Garnier et al. 2007, Perdue et al. 1981), and that there is growing evidence that contaminants may be partly responsible for the observed increase in disease and mortality in C gigas, by adversely affecting their defence mechanisms (Lacoste et al. 2001, Perdue et al. 1981).

Marennes-Oléron Bay is a suitable area to assess the effects that contaminants have on biomarker responses of the Pacific oyster C. gigas, since it is the first production site of C. gigas in France (Soletchnik et al. 1999), one of the most important production sites at the worldwide level (FAO 2010), and because this area accounts for high levels of a wide range of anthropogenic contaminants such as heavy metals, polycyclic aromatic hydrocarbons (PAHs) and persistent organic pollutants (POPs; Miramand et al. 2003, Munaron et al. 2006). In the Marennes-Oléron Bay, contaminants are mainly transported by the Charente River and to a less extent by the Seudre River (Miramand et al. 2003, Munaron et al. 2006, Luna-Acosta et al. 2010a). The bay is also influenced by inputs from the biggest 
estuary in occidental Europe, the Gironde Estuary (Miramand et al. 2003, Munaron et al. 2006). In addition, in previous studies, Bouin (B) has been considered as a reference site for chemical contamination (Geffard et al. 2002).

Therefore, the main goals of this transplantation study were to evaluate: 1) PAH and POP body burdens in transplanted juvenile oysters after a three-month transplantation period in summer and winter, in different sites of the Marennes-Oléron Bay and the Gironde Estuary; 2) the potential effects of exposure to organic contaminants on antioxidant defence responses, immune defence responses, energy reserves and condition index in juveniles of $C$. gigas; 3 ) the potential effects of internal (i.e. physiological status) and/or external (i.e. environmental) factors on juvenile oyster biomarker responses; and 4) the potential use of transplanted juvenile oysters to differentiate sites depending on their contamination levels and biological effects.

Juvenile oysters bought in a hatchery were transferred in summer and winter to B and to different transplantation sites in the Marennes-Oléron Bay and the Gironde Estuary. After a three-month transplantation period, for each site and season, body burdens of PAHs and POPs (polychlorobiphenyls PCBs-, polybromodimethylethers -PBDEs- and organochlorine pesticides -OCPs-), were analysed and biochemical biomarker responses (SOD, CAT GPx, MDA, catecholase, laccase and lysozyme) were measured in different tissues (gills, digestive gland, mantle and haemolymph). Additionally, energy reserves (glycogen, proteins and lipids) in the digestive gland and the condition index were analysed, and environmental data from French monitoring networks were collected.

\section{Materials and methods}

\subsection{Study area and transplant design}

Juvenile Pacific oysters $C$. gigas from same size, $3-4 \mathrm{~cm}$ in height (1 year-old), were purchased from the oyster hatchery France Naissain, located in Vendée (France) at the beginning of each transplantation 
period, in summer and winter. All animals were issued from the same breeding population in order to reduce genotype variability. In April 2008 and in October 2008, oysters were transplanted to Bouin (B; $46^{\circ} 58^{\prime} 28^{\prime \prime} \mathrm{N}, 2^{\circ} 00^{\prime} 02^{\prime} \mathrm{W}$ ), considered as a reference site (Fig. 1a), since it is located in a zone near the oyster hatchery where oyster were purchased and because it possesses different seawater physicochemical characteristics in comparison to the transplantation zone (Geffard et al. 2002). In April 2008 and in October 2008, oysters were also transplanted into four other sites, considered as the transplantation

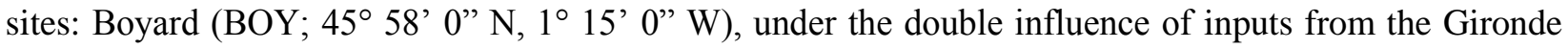
and the Charente estuaries; Les Palles (LP; $\left.45^{\circ} 58^{\prime} 0^{\prime \prime} \mathrm{N}, 1^{\circ} 08^{\prime} 0^{\prime \prime} \mathrm{W}\right)$, highly influenced by inputs from the Charente River; Mus du Loup (ML; $45^{\circ} 46^{\prime} 10^{\prime}$ N, $1^{\circ} 08^{\prime} 30^{\prime}$ W), mildly influenced by inputs from the Seudre River, and Cordouan (C; $45^{\circ} 35^{\prime} 11^{\prime \prime} \mathrm{N}, 1^{\circ} 10^{\prime} 24^{\prime}$ ' W), highly influenced by inputs from the Gironde Estuary (Fig. 1b). Transplantation was carried out for a period of three months (90 days), from April to June 2008 (summer season) and from October to December 2008 (winter season). For each site and season, a total of 100 individuals were placed in HDPE (high-density polyethylene) oyster bags, all with the same size $(1 \mathrm{~m} \times 0.5 \mathrm{~m})$ and the same mesh size $(2 \mathrm{~cm})$. For each site, all individuals were transplanted in the same oyster bag and at the same location, and oyster bags were placed on oyster aquaculture tables. These tables were placed at a height of $40 \mathrm{~cm}$ from the substrate, and all located on the same hypsometric level (iso-altitude of about $1 \mathrm{~m}$ corresponding to low-tide water level, coefficient 90 ), in order to have an equivalent immersion time $(<15 \%$ of the time over a tidal cycle) for all the individuals that were transplanted, regardless of the geographic location. Three months after each transplantation period (in June 2008 and in December 2008) and for each site (B, BOY, LP, ML and C), 5 oysters were randomly collected for condition index and chemical analyses, and 9 oysters were collected for biochemical biomarkers and energetic reserves analyses. Oysters were transported in ice bags and processed immediately after their arrival in the laboratory. 


\subsection{Sample procedure}

Back in the laboratory, the 5 oysters collected for condition index and chemical analyses, were processed as follows: soft tissues were removed from the shells, homogenized using an Ultra Turrax (T25 basic, IKA-WERKE) and a Thomas-Potter homogenizer (IKA-Labortechnik RW 20.n, size 0.13-0.18 $\mathrm{mm}$ ), freeze-dried and weighted (dry weight; $\mathrm{dw}$ ) for flesh $\mathrm{dw}$, shell $\mathrm{dw}$ and condition index analyses $\left(\mathrm{n}=5\right.$, per site and per season), and then pooled and frozen $\left(-80^{\circ} \mathrm{C}\right)$ for chemical analyses. For chemical analyses, three replicate analyses were carried out per site and per season $(n=3,1$ sample replicate from 5 oysters analyzed in triplicate, per site and per season).

For the other biological analyses, the 9 oysters collected for biochemical biomarkers and energetic reserve analyses were processed as follows: pooled gills, digestive glands, mantles, and plasma of three oysters were used for each replicate sample, and three replicates were prepared per site and per season $(n=9,3$ sample replicates from 3 oysters each, per site and per season). To collect these samples, after opening the oyster shells by cutting off the adductor muscle, a quantity of haemolymph $(\sim 0.3-0.5 \mathrm{ml}$ for the three oysters) was withdrawn and centrifuged $\left(260 \mathrm{~g}, 10 \mathrm{~min}, 4^{\circ} \mathrm{C}\right)$ to separate the cellular fraction from the plasma. The gills, digestive gland and mantle were removed from the soft tissues and homogenized at $4^{\circ} \mathrm{C}$ in $0.1 \mathrm{M}$ Tris $\mathrm{HCl}$ buffer $\mathrm{pH} 7.0\left(0.45 \mathrm{M} \mathrm{NaCl}, 26 \mathrm{mM} \mathrm{MgCl} 2,10 \mathrm{mM} \mathrm{CaCl}_{2} ; 0.5 \mathrm{ml}\right.$ of buffer. $\mathrm{g}^{-1}$ of fresh weight for the gills and the mantle, and $1 \mathrm{ml.g} \mathrm{g}^{-1}$ of fresh weight for the digestive gland), using an Ultra Turrax (T25 basic, IKA-WERKE) and a Thomas-Potter homogenizer (IKALabortechnik RW 20.n, size 0.13-0.18 mm). The homogenate was centrifuged at $10000 \mathrm{~g}$ for $10 \mathrm{~min}$ at $4^{\circ} \mathrm{C}$. The resulting supernatant was collected for enzymatic analyses. 


\subsection{Chemical analysis}

A total of 31 polyaromatic hydrocarbon (PAH), 10 polychlorobiphenyl (PCB), 4 polybromodimethylether (PBDE), and 13 organochlorine pesticide (OCP) compounds were quantified and concentrations of organic contaminants were expressed in $\mu \mathrm{g} \mathrm{kg}^{-1}$ dry weight (dw). Briefly, PAHs were measured using a gas chromatograph (HP 6890. Agilent technologies, Palo Alto, CA, USA) equipped with a splitless injector and coupled to a MSD 5975 mass spectrometer (Baumard et al. 1999). PCBs, PBDEs and OCPs were quantified using a gas chromatograph (HP 5890 Hewlett Packard, Palo Alto, Ca, USA) equipped with a splitless injector and coupled to an electron capture detector (Thompson \& Budzinski 2000; Tapie et al. 2008) and confirmed using a gas chromatograph (Agilent Technologies 7890A) coupled to MS/MS (Agilent technologies 7000). Among pesticides, lindane, 2,4'- and 4,4'dichlorodiphenyltrichloroethanes (DDT), 2,4'- and 4,4'-dichlorodiphenyldichloroethanes (DDE), and 2,4'- and 4,4'-dichlorodiphenyldichloroethylenes (DDD), hexachlorobenzene (HCB), heptachlor (HC) and trans-nonachlor (TNC) were quantified. In the text, we will refer to the sum of all DDTs and their metabolites (DDEs and DDDs) as 'DDTs' and to the sum of HCB, HC and TNC as 'HCB+HC+TNC'. More details on the methodology and quality control are described in Luna-Acosta et al. (submitted for this volume).

\subsection{Biological analysis}

Superoxide dismutase (SOD) assay • SOD was determined by an indirect method (Therond et al. 1996), based on competition of SOD with iodonitrotetrazolium (INT) for dismutation of superoxide anion $\left(\mathrm{O}_{2}^{-}\right)$. In the presence of $\mathrm{O}_{2}^{-}$, INT is reduced into a red formazan dye that can be measured at $505 \mathrm{~nm}$ at $25^{\circ} \mathrm{C}$ (Ransod SD 125 Kit, Randox, France). One unit of SOD is defined as the amount of enzyme that promotes a $50 \%$ decrease in the rate of INT reduction. 
Catalase (CAT) assay • Catalase activity was determined according to the method of Fossati et al. (1980). This assay method is based on the measurement of the hydrogen peroxide substrate remaining after the action of catalase. First, catalase converts hydrogen peroxide to water and oxygen and then this enzymatic reaction is stopped with sodium azide. An aliquot of the reaction mix is then assayed for the amount of hydrogen peroxide remaining by a colorimetric method (Catalase Kit CAT-100, Sigma).

Glutathione peroxidase (GPx) assay $\bullet$ GPx activity was determined according to the method of Paglia \& Valentine (1967). In the presence of glutathione reductase and substrates (i.e. reduced glutathione and cumene hydroperoxide), the decrease of absorbance at $340 \mathrm{~nm}$ is proportional to the reduction of the oxidised glutathione by NADPH, H+ (Ransel RS 504 Kit, Randox, France). One unit of GPx oxidizes 1 nmol of NADPH $\left(\varepsilon=6.22 \mathrm{mM}^{-1} \mathrm{~cm}^{-1}\right)$ per minute.

Phenoloxidase (PO, catecholase- and laccase-type) assay •In C. gigas, catecholase- and laccase-type PO activities have been detected in C. gigas (Luna-Acosta et al. 2010b). Spectrophotometric measurements of these PO activities were made as described in Luna-Acosta et al. (2010b). Assays were carried out in triplicate for each sample. Briefly, catecholase-type PO assay was carried out in the presence of $100 \mathrm{mM}$ dopamine and 0.1 M Tris $\mathrm{HCl}$ buffer, pH 7.0 (0.45 M NaCl, $26 \mathrm{mM} \mathrm{MgCl}$, $10 \mathrm{mM} \mathrm{CaCl} 2$; SigmaAldrich, France). Catecholase activity was followed by monitoring the increase of absorbance at $490 \mathrm{~nm}$ for $4 \mathrm{~h}$. Laccase assay was carried out in the presence of $50 \mathrm{mM}$ of $\mathrm{p}$-phenylenediamine (PPD), diluted in methanol, and 0.1 M Tris $\mathrm{HCl}$ buffer, $\mathrm{pH}$ 7.0. Laccase activity was followed by monitoring the increase of absorbance at $420 \mathrm{~nm}$ for $2 \mathrm{~h}$. Non-enzymatic oxidation of the substrate was followed in wells without oyster sample and subtracted to oxidation of the substrate with oyster sample. One unit of catecholase specific activity and one unit of laccase specific activity corresponds to the amount of enzyme that catalyzes the production of $1 \mu$ mole of product $\left(\varepsilon=3300 \mathrm{M}^{-1} \cdot \mathrm{cm}^{-1}\right.$ and $43160 \mathrm{M}^{-1} \cdot \mathrm{cm}^{-1}$, respectively), per minute and per milligram of protein (Eggert et al. 1996, Espin et al. 1995). 
Lysozyme assay • Lysozyme assay was done in triplicate for each sample and compared against hen egg white lysozyme standards $\left(0.4-40 \mu \mathrm{g} \cdot \mathrm{ml}^{-1}\right)$, in the presence of Micrococcus lysodeikticus (Sigma-Aldrich, France). One unit of lysozyme corresponds to the amount of enzyme that diminishes absorbance at 450 $\mathrm{nm}$ of 0.001 per minute at $\mathrm{pH} 7.0$. at $25^{\circ} \mathrm{C}$ (Soudant et al. 2004).

Malondialdehyde (MDA) assay $\bullet$ Lipid peroxides, derived from polyunsaturated fatty acids, are unstable and decompose to form a complex of series of compounds, of which the most abundant is MDA (GerardMonnier et al. 1998). The method to determine MDA levels in the gills and the digestive gland (MDA586, Oxis Research, Portland, OR, USA) was based on the reaction of a chromogenic reagent, N-methyl2-phenylindole (NMPI) with MDA at $45^{\circ} \mathrm{C}$. One molecule of MDA reacts with two molecules of NMPI to yield a stable carbocyanine dye with maximum absorption at $586 \mathrm{nnm}$. The MDA in the sample was determined from the sample's absorbance at $586 \mathrm{~nm}$ and the standard curve was prepared using the MDA standard provided in the kit.

Glycogen assay • Digestive gland samples were freeze dried and weighed before determining glycogen, lipids and protein contents. Glycogen content (precipitated with absolute ethanol) was quantified using the phenol-sulphuric method as described by Dubois et al. (1956). Known glucose standards were processed in the same way as the samples and used to construct a calibration curve.

Lipid assay • Lipids were extracted according to the procedure of Folch et al. (1956). A double static extraction $(2 \times 12 h)$ was carried out on the rehydrated samples with a chloroform:methanol mix (1:2 then 2:1, v/v) in polytetrafluoroethylene (PTFE)-capped tubes held at $4^{\circ} \mathrm{C}$, under a nitrogen atmosphere. Following the addition of a salt solution $(\mathrm{NaCl} 1 \%)$, the crude extract was separated into two phases. The lower chloroform phase containing lipids was washed gently with a new volume of the upper phase. After centrifugation for $10 \mathrm{~min}$ at $3000 \mathrm{~g}$ at $10^{\circ} \mathrm{C}$ and decantation, it was recovered and stored at $-20^{\circ} \mathrm{C}$ until 
analysis. Total lipids were measured using a Iatroscan-Chromarod system (thin layer chromatographyflame ionization detection (TLC-FID)) connected to a Shimadzu CR3A integrator. Five successive volumes $(1 \mu \mathrm{l})$ of a concentrated extract aliquot were spotted on a Chromarod SIII silica rod with a $2 \mu \mathrm{l}$ Hamilton microsyringe. After drying in a dessicator, the rod was read directly by the Iatroscan without any development. A calibration curve based on a total lipid extract from cod liver oil, with similar lipid characteristics than oyster tissues, was used to calculate the lipid concentration of the sample extracts.

Protein assay • Protein concentration measured according to the Lowry method with slight modifications, by using bicinchoninic acid and copper sulphate $4 \%$ (Smith et al. 1985). Serum albumin was used as standard (Sigma-Aldrich, France). All enzyme activities were expressed in relation to protein concentration.

Condition index $•$ Condition index in juvenile oysters was calculated by the method of Lobel and Wright (1982), and expressed in mg flesh dry weight $\mathrm{g}^{-1}$ shell dry weight.

\subsection{Statistical analysis}

All values are reported as mean \pm standard deviation $(S D ; n=5$, per site and season, for flesh dry weight, shell dry weight and condition index analyses; $n=3$, per site and per season, for chemical analyses and $n=9$, per site and season, for biochemical biomarkers and energetic reserve analyses). Values were tested for normality (Shapiro test) and homogeneity of variances (Bartlett test). In some cases (HPAHs, PCBs, PBDEs, DDTs, lindane and $\mathrm{HCB}+\mathrm{HC}+\mathrm{TNC}$ body burdens, catecholase, laccase, lysozyme in gills, GPx, MDA, lysozyme, proteins and lipids in the digestive gland, SOD, GPx, catecholase, and lysozyme in mantle and SOD, CAT, laccase and lysozyme in plasma), logarithmic transformations (Log10) were used to meet the underlying assumptions of normality and homogeneity of variances. Since body size and/or 
gross body state may influence biomarker responses (Packard \& Boardman 1999), two-way MANCOVAs (covariate: flesh dw, shell dw or condition index), were carried out to evaluate these possible effects, with site and season as fixed factors (Zar 1984). After verifying that the tested covariates had no significant effect on biomarker responses ( $p>0.05$ ), a two-way MANOVA was used, with site and season as fixed factors. When the null hypothesis $\left(\mathrm{H}_{0}\right.$ : no difference between sites or within sites at different seasons) was rejected, significant differences were tested using Tukey's HSD test. Statistical significance was designed as being at the level of $\mathrm{p}<0.05$. In addition, a discriminant analysis (DA; using three different groups of sites depending on their degree of contamination, in order to test which biomarker responses significantly contributed to discriminate sites between these three groups) and the ordination technique of redundancy analysis (RDA; using forward selection of explanatory variables, in order to test which contaminants had a significant effect on the observed biomarker responses) were performed to evaluate the response of biomarkers to chemical analyses. Data were centered and standardized before analysis. The significance of the relationship between biomarker responses and contaminant body burdens were tested using a global Monte Carlo permutation test. Statistical analyses of data were performed using the software STATISTICA 7.0, with the exception of DA and RDA that were performed using the software XLSTAT 5.0 .

\section{Results and discussion}

\subsection{PAH and POP body burdens in transplanted juvenile oyster}

In the present study, over the different sampling stations (i.e. reference and transplantation sites) and seasons (i.e. summer and winter), body burdens ranged between $27 \pm 1$ and $68 \pm 19 \mu \mathrm{g} \mathrm{kg}^{-1} \mathrm{dw}$ for LPAHs, between $35 \pm 7$ and $159 \pm 34 \mu \mathrm{g} \mathrm{kg}^{-1} \mathrm{dw}$ for HPAHs, between $15 \pm 1$ and $89 \pm 39 \mu \mathrm{g} \mathrm{kg}^{-1} \mathrm{dw}_{\text {for PCBs, }}$ between $0.4 \pm 0.0$ and $2.9 \pm 0.7 \mu \mathrm{g} \mathrm{kg}^{-1} \mathrm{dw}$ for PBDEs, between $2 \pm 0$ and $15 \pm 0 \mu \mathrm{g} \mathrm{kg}^{-1} \mathrm{dw}$ for DDTs, between $0.1 \pm 0.0$ and $2.2 \pm 1.1 \mu \mathrm{g} \mathrm{kg}^{-1} \mathrm{dw}$ for lindane, and between $0.7 \pm 0.0$ and $3.5 \pm 1.0 \mu \mathrm{g} \mathrm{kg}^{-1} \mathrm{dw} \mathrm{HCB}+\mathrm{HC}+\mathrm{TNC}$ 
(Table 1). Transplanted oysters with the highest HPAH and DDT body burdens were observed in LP in summer and LP, BOY and ML in winter (Table 1). Surprisingly, transplanted oysters with the highest PCB, PBDE and lindane body burdens, were observed in B, considered as a reference site for chemical contamination in previous studies (e.g. Geffard et al. 2002; Table 1). Results of the present study reveal that B should no longer be considered as a reference site and show that special care must be taken in future studies, since it should not be considered as a reference site for a certain type of contaminants, such as metals but no others, such as chemical organic contaminants. Previous authors have pointed out the difficulty to establish a reference site that is not polluted (Davies \& Vethaak 2012), and some of authors have even argued that there is no such thing as a pristine environment (Clark 1982). Thus, B remains an interesting site in the present study, since it is located in a zone near the oyster hatchery where oyster were purchased and because it possesses different seawater physico-chemical characteristics in comparison to the transplantation zone (Geffard et al. 2002). Moreover, although it is difficult to determine the normal range of biomarker responses in the present study, the chemical compounds that are analyzed in the present study are not naturally present in animals so their presence unequivocally indicate the presence of environmental pollution and therefore findings of the present study are not compromised since relationships between biomarkers response and exposure can still be determined.

Another interesting result was that oysters from $\mathrm{C}$, located in the Gironde Estuary, did not have the highest body burdens for the organic contaminants analysed in the present study (Table 1), suggesting that the Marennes-Oléron Bay is not subjected to chronic pollution by PAHs or POPs from the Gironde watershed. These results were not expected since the Marennes-Oléron Bay is known to be influenced by the historic polymetallic pollution of the Gironde Estuary, especially of Cadmium (Pigeot et al. 2006, Strady et al. 2011), and therefore the Bay was expected to be influenced by other contaminants, such as PAHs and POPs, of the Gironde Estuary (Laroche et al. 2013). These results suggest also the presence of other contaminant sources in the Marennes-Oléron Bay, such as local inputs from agricultural or industrial activities, as more deeply discussed in Luna-Acosta et al. (submitted to this volume) and are in agreement 
with different studies (e.g. Greenfield et al. 2014, Hédouin et al. 2011, Orbea \& Cajaraville 2006) that show that transplant experiments with bivalves could be useful to assess the origin of chemical pollution.

\subsection{Potential effects of exposure to organic contaminants on antioxidant defence responses, immune defence responses, energy reserves and condition index in juveniles of $C$. gigas}

General trends of biomarker responses in oysters from transplantation sites in the MarennesOléron Bay and the Gironde Estuary are presented in this paragraph in comparison to biomarker responses in oysters from B (Table 2). SOD levels were generally significantly higher, especially in LP and BOY, except when they were measured in the gills (Table 2). CAT levels were also significantly higher, when measured in the digestive gland or in plasma (Table 2). GPx levels were significantly lower or higher, depending on the analysed tissue and season (Table 2). MDA levels were generally significantly higher in the gills and in the digestive gland, especially in winter (Table 2). Catecholase levels were higher when measured in the gills and the digestive gland and lower when measured in plasma, especially in summer (Table 2). Laccase levels were lower, independently of the season (Table 2), and lysozyme levels were lower, except when measured in winter in the digestive gland (Table 2). Thus, as a general trend, higher levels of SOD, CAT, GPx, MDA, catecholase, laccase and lysozyme were observed in winter.

Humoral immune defence responses of the present study are in agreement with previous studies that have reported lower immune defences in summer (Samain et al. 2007). However, the latter has generally been attributed to the reproductive cycle of bivalves in summer (Samain et al. 2007), and in the present study oysters were juveniles. Results on MDA levels in the present study are in agreement with previous studies in bivalves that have reported higher oxidative stress in winter, but results on SOD, CAT and GPx are in disagreement with previous studies in bivalves that have reported that generally antioxidant defences in bivalves are lower in winter (Manduzio et al. 2004). Thus, factors other than the seasonality are likely to affect biomarker responses in the present study. 
Concerning other biomarker responses analysed in the present study, glycogen, lipid and proteins in the digestive gland generally accounted for 5-15\%, 60-70\% and 10-20\% of the total energy reserves, respectively (Fig. 2b, c), and varied also depending on the season and site (Fig. 2a). A significant decrease in lipid contents was observed between summer and winter, in oysters from B (Fig. 2a). When analysing results from other sites, low, not significant, levels in oysters from BOY, LP and C were concomitant with significant high levels in lipids and proteins. Low glycogen levels could be due to an exposure of the organism to high levels of contaminants (Pellerin-Massicotte et al. 1994) or the use of glycogen reserves in oysters for the synthesis of lipids and/or proteins for gametogenesis (De La Parra et al. 2005, Gabbott 1975). High levels of glycogen in ML in summer, concomitant with low levels of lipids and proteins, could suggest a delay in the gametogenesis in this site (Gauthier-Clerc et al. 2002) or that organisms in this site were not exposed to high levels of contaminants. When comparing these results to the total flesh dry weight, the digestive gland weight in oysters from BOY, LP, ML and C was lower in summer than in winter (Fig. 2b), and this could be associated to gametogenesis (De La Parra et al. 2005). However, further studies should be carried out to verify this hypothesis.

In the present study, higher condition index values were observed in summer in comparison to winter (Fig. 3c). These results are in agreement with previous studies in mussels and oysters (Bodin et al. 2004, Soletchnik et al. 2006). Interestingly, significant differences between reference and transplantation sites were observed in summer but not in winter. In summer, a significant increase of the condition index was observed in a North-South gradient, with higher values observed in C: in comparison to the condition index of oysters from $\mathrm{B}$, the condition index was $\sim 1.3, \sim 1.3, \sim 1.7$ and $\sim 2$-fold significantly higher in BOY, LP, ML and C, respectively. This increase in the condition index was not due to an important increase in shell dry weight (Fig. 3b), but to an important increase in flesh dry weight (Fig. 3a). However, no clear differences in contaminant body burdens between sites were observed in a North-South gradient. To further evaluate potential relationships between biomarker responses and contaminant body burdens, a DA analysis was carried out dividing sites into three groups, based on contaminant body burdens (Table 
1): group 1 corresponded to $\mathrm{B}$ in summer and winter (Bs and $\mathrm{Bw}$, respectively), which showed to be the most contaminated site concerning PCB, PBDE and lindane contamination, group 2 corresponded to Les Palles in summer and winter, Boyard in winter and Mus du Loup in winter, which showed to be the most contaminated sites concerning HPAH and DDT contamination (Table 1), and group 3 corresponded to the remaining sites (Boyard and Mus du Loup in summer and Cordouan in summer and winter). Biomarker responses that significantly $(\mathrm{p}<0.001)$ contributed to discriminate sites into these three groups were: MDA in gills, SOD, GPx, MDA, lysozyme and proteins in the digestive gland, SOD in the mantle, SOD, GPx and laccase in plasma and the condition index. The RDA analysis was carried out with these biomarkers.

The results of the RDA analysis are presented in the tri-plot ordination diagram of Fig. 4. Among contaminants that were analysed, HPAHs, PCBs, PBDEs, DDTs and lindane had a significant effect on the observed biomarker responses. The first two axes of the RDA analysis accounted for $77 \%$ of the overall variability of the data. Therefore, the other axes were neglected because they did not provide significant additional information. The first RDA axis (horizontal) accounted for $42 \%$ of the total, and HPAHs and DDTs strongly correlated with the first axis. In addition, MDA in the gills and the digestive gland, SOD in mantle and SOD and GPx in plasma correlated positively with the first axis and the condition index correlated negatively with the first axis (Fig. 4a).

The second RDA axis (vertical) accounted for $35 \%$ of the total variability of the data and the levels of PCBs, PBDEs and lindane strongly correlated with the second axis. In addition, GPx in the digestive gland and laccase in the plasma and mantle correlated positively with the second axis, and SOD in the digestive gland correlated negatively with the second axis (Fig. 4a).

Thus, results of the RDA analysis suggest that HPAH and/or DDT contamination increase SOD activities in the mantle, and SOD and GPx activities in plasma and that PCB, PBDE and/or lindane contamination increase GPx activities in the digestive gland (Fig. 4a). The observed results could be explained by the fact that PAHs can lead to the formation of ROS and enhance oxidative stress in aquatic organisms (Di Giulio et al. 1989, Winston 1991). Indeed, different studies have shown an increase in SOD 
activity in bivalves exposed to hydrocarbons (Orbea et al. 2002, Richardson et al. 2008, Sole et al. 1995), suggesting that hydrocarbons induced oxidative stress by producing ROS such as $\mathrm{O}_{2}^{-}$. A significant correlation between PAH accumulation in the flesh and SOD and CAT activities in the gills has been found in mussels from the Mediterranean Sea (Porte et al. 1991). Sole et al. (1995) also reported correlations between GPx activity in the digestive gland of molluscs collected on the Mediterranean coast and their organochlorine body burden and SOD activity in the digestive gland and PAH concentrations. Krishnakumar et al. (1995) reported higher CAT activity in the digestive gland of mussels from contaminated sites when compared to those sampled at a reference site in the North American Pacific coast. Consistently, increased antioxidant activities were found in oysters from contaminated sites by PCBs, PAHs and pesticides (Rodriguez-Ariza et al. 1993). In the present study, results suggest also that HPAH and/or DDT contamination increase MDA levels in the gills and digestive gland.

SOD activities in the digestive gland correlated negatively with the second RDA axis (Fig. 4a). These results suggest that $\mathrm{PCB}, \mathrm{PBDE}$ and/or lindane contamination decrease SOD activities in digestive gland. This could be due to the inhibition of the enzyme synthesis by these contaminants or to an enzyme inactivation caused by high tissue contaminant concentrations, as it has been suggested for other contaminants (Borg \& Schaich 1983).

Laccase in plasma and mantle correlated positively with the second RDA axis (Fig. 4a). These results suggest that $\mathrm{PCB}, \mathrm{PBDE}$ and/or lindane contamination increase laccase activities in plasma (Fig. 4a). Thus, laccase activity may enable a protection against bioaccumulated PCBs, PBDEs and lindane, and therefore, be a potential defence biomarker candidate in ecotoxicological studies, as suggested in previous studies (Luna-Acosta et al. 2011a, b). However, there is a lack of fundamental understanding of the activation and regulation of key factors of catecholase-type and laccase-type PO pathways in bivalves. Thus, more studies on the potential roles of these enzymes in oysters are needed for a better understanding of the potential implications of their modulations in the presence of contaminants. 
Results of the RDA analysis suggest also that PCB, PBDE and/or lindane contamination increase lysozyme activities in the digestive gland (Fig. 4a), suggesting that lysozyme play a role in the detoxification of PCB, PBDE and/or lindane in C. gigas.

Proteins in the digestive gland correlated negatively with the second RDA axis (Fig. 4a). This result suggests a negative correlation between protein contents in the digestive gland and PCB, PBDE and lindane levels and therefore are in agreement with the hypothesis that contaminants may exert an effect on oyster energy reserves, i.e. that the exposure to contaminants induces a lower accumulation of energy reserves or that energy reserves are deployed in the presence of these contaminants for the proper activation of defence mechanisms. However, no correlations were observed between lipid and glycogen levels in the digestive gland, and contaminant body burdens. Therefore, more studies are needed to better assess the relationship between contaminant contents and energy reserves in bivalves.

HPAHs and DDTs strongly correlated with the first RDA axis and the condition index correlated negatively with the first axis (Fig. 4a). This result suggests negative correlations between condition index and HPAH and DDT contents, suggesting that these contaminants may exert a negative effect in oyster condition index. However, the clear North-South gradient on condition index values in summer (Fig. 3c), suggests that other internal or external factors could have an effect on the condition index.

\subsection{Potential effects of internal and external factors on juvenile oyster biomarker responses}

Possible effects on biomarker responses could be attributed to internal factors, such as oyster body size or gross body state (Packard \& Boardman 1999), estimated in the present study through flesh dw, shell $\mathrm{dw}$ and condition index. MANCOVA analyses revealed no significant effect of the tested covariates on biomarker responses, suggesting that oyster body size or gross body state had no effect on biomarker responses. 
Possible effects on biomarker responses could also be attributed to external environmental factors. Data collected from 2000 to 2006, and from 2008, from French monitoring networks in the same area of the present study (Table 3), suggests that differences in some environmental parameters between sites follow a North-South gradient: a slight increase of the temperature was observed in a North-South gradient in summer, higher levels of turbidity were observed in winter, especially in B, BOY and LP, and differences in phytoplankton abundance and species composition were observed between sites and seasons, with higher abundance of phytoplankton and species composition observed in summer, especially in $\mathrm{C}$ (Table 3). However, no clear modulations on biomarker responses were observed in a North-South gradient in the present study, with the exception of the condition index (Fig. 3c). It is important to mention that the condition index varies principally with the availability and/or the quality of the food (Mourgaud et al. 2002). Therefore, results of the present study suggest that trophic quality is better in $C$ than in the other sites, and also, that, in the present study, the condition index is more influenced by the seawater temperature or the presence and/or quality of food, than by contaminants. Among other environmental variables (salinity, presence of phycotoxins, faecal contamination), no particular differences were observed between sites and seasons (Table 3).

Overall, with the exception of the condition index, these results suggest that environmental factors, such as temperature, salinity, turbidity, phytoplankton abundance and species composition, phycotoxins and faecal contamination, were not the main causes of variations on biomarker responses between sites and seasons. However, further studies should be carried out to verify this hypothesis.

\subsection{Use of transplanted juvenile oysters to differentiate sites depending on their contamination levels and biological effects}

Site sample analysis (Fig. 4b) shows three well-defined groups, depending on levels of contaminants: 1) the first group, with $\mathrm{Bs}$ and $\mathrm{Bw}$, is clearly defined by the levels of PCBs, PBDEs and 
lindane, 2) the second group, with Les Palles in summer (LPs) and winter (LPw), Boyard in winter (BOYw) and Mus du Loup in winter (MLw), is clearly defined by the levels of HPAHs and DDTs, and 3) the third group encompasses all the other sites, i.e. BOY in summer (BOYs), ML in summer (MLs) and Cordouan in summer $(\mathrm{Cs})$ and winter $(\mathrm{Cw})$. Similar correlations were observed between contaminant levels and MDA in gills and digestive gland and between contaminant levels and SOD in plasma and mantle (Fig. 4a), suggesting that, if only two tissues should be selected for in situ studies in C. gigas, measurement of MDA only in the digestive gland and measurement of SOD only in plasma, would be enough to discriminate sites with high levels of HPAH and DDT contamination. In addition, GPx in plasma could also contribute to discriminate sites with high levels of HPAH and DDT contamination. On the other hand, SOD and lysozyme in the digestive gland, and laccase in plasma could contribute to discriminate sites with high levels of PCB, PBDE and lindane contamination. Thus, in the present study, SOD, GPx, MDA, laccase, lysozyme and proteins in the digestive gland and SOD, GPx and laccase in plasma contributed to discriminate sites, with more evident bioaccumulation of organic pollutants, especially HPAHs, DDTs, PCBs, PBDEs and lindane.

In a transplantation study carried out in the Ebro Delta (NE Spain) with the freshwater clam (Corbicula fluminea) for a 3-month period, measured biomarker responses (antioxidant and esterase enzyme responses, and lipid peroxidation) showed marked differences across sites and months, depending on the levels of pesticides present in these sites (Damasio et al. 2010). In a transplantation study in the Cecine River (Italy), the freshwater painter's mussel (Unio pictorum) was transplanted for 4 weeks (1 month) in different locations of the river basin and the bioaccumulation of metals was integrated with a wide battery of biomarkers consisting of oxidative, genotoxic and lysosomal responses (Guidi et al. 2010). Considering the mild contamination gradient in the investigated area, the overall results suggested that some oxidative biomarkers, as well as those evaluating chromosomal and cell damages, were highly sensitive and could be profitably applied to caged painter's mussels for environmental quality assessment in freshwater. In a transplantation study in the South coast of Portugal, transplanted mussels Mytilus 
galloprovincialis had significant alteration in some biomarkers that reflected the type of contaminants present in each site (metals or PAHs), and the biomarkers that better differentiate the impact of different contaminants at each site were metallothioneins, cytochrome P450, SOD and CAT, measured in the digestive gland. Thus, results of the present study in are in agreement with previous in situ studies in which biomarker responses have shown marked differences across sites depending on the level of contamination.

\section{Conclusion}

In conclusion, among the battery of biomarkers applied in the present work (including antioxidant defence mechanisms, humoral immune defence mechanisms, and physiological biomarkers), MDA and lysozyme in the digestive gland and SOD, GPx and laccase in plasma allowed to significantly discriminate sites in which oysters bioaccumulated different levels of HPAHs, DDTs, PCBs, PBDEs and lindane. In combination with other recent studies, these results strengthen the hypothesis that it is possible to differentiate sites depending on their contamination levels and biological effects by carrying out studies with transplanted juvenile oysters.

Interestingly, SOD, GPx and MDA levels were positively correlated to HPAH and DDT body burdens and were associated to different sites in the Marennes-Oléron Bay (LP, BOY and ML). These results suggest a potential oxidative stress, leading to lipid peroxidation in juvenile oysters, and seems to be related not to external inputs from the Gironde Estuary, but to local inputs of HPAHs and DDTs, probably from the Charente and the Seudre rivers. An increase in oxidative stress and lipid peroxidation could affect defence mechanisms in juvenile oysters, which may contribute to the increase in disease and mortality of C. gigas, observed in the Marennes-Oléron Bay. Therefore, more studies should be done to further examine the effects of these organic contaminants on $C$. gigas. 


\section{Acknowledgments}

This study was supported by a PhD grant from the Conseil Général de the Charente-Maritime for A. LunaAcosta. Authors wish to thank M. Baudrimont and D. Fichet for supporting this study through the 'Défi Cadmium' project, financed by Région Poitou-Charentes, Région Aquitaine, Conseil Général de la Charente-Maritime, Conseil Général de la Gironde, and Agence de l'Eau Adour-Garonne. CPER A2E is also acknowledged for financial support. Authors acknowledge also R. Galois and M. Metian for their scientific advice for lipid and glycogen content and condition index analyses, M. Caille, J. Laheux and M. Pelmoine for their assistance during the study, and the Ifremer networks ROCCH and RAZLEC, the 'Site Ifremer consacré à l'environnement littoral' and especially O. Le Moine, P. Soletchnik, S. Guesdon, P-G. Sauriau, P. Miramand and T. Guyot, for data and references from Marennes-Oléron Bay. Authors acknowledge also C. Trichet and D. Vilday for their technical assistance during the study. Authors wish to warmly thank also T. Caquet and P. Legendre for their scientific advice and help in statistical analyses.

\section{References}

Auffret M, Duchemin M, Rousswater S, Boutet I, Tanguy A, Moraga D, Marhic A. Monitoring of immunotoxic responses in oysters reared in areas contaminated by "Erika" oil spill. Aquat Liv Res 2004; 17:297-302.

Allan IJ, Vrana B, Greenwood R, Mills GA, Roig B, Gonzalez C. A “toolbox” for biological and chemical monitoring requirements for the European Union's Water Framework Directive. Talanta 2006; 69:302322.

Baumard P, Budzinski H, Garrigues P, Dizer H, Hansen PD. Polycyclic aromatic hydrocarbons in recent sediments and mussels (Mytilus edulis) from the Western Baltic Sea: occurrence, bioavailability and seasonal variations. Mar Environ Res 1999; 47:17-47. 
Beninger PG, Lucas A. Seasonal variations in condition, reproductive activity, and gross biochemical composition of two species of adult clam reared in a common habitat: Tapes decussatus L. (Jeffreys) and Tapes philippinarum (Adams \& Reeve). J Exp Mar Biol Ecol 1984; 79:19-37.

Besse JP, Geffard O, Coquery M. Relevance and applicability of active biomonitoring in continental waters under the Water Framework Directive. Trend Anal Chem 2012; 36:113-127.

Bodin N, Burgeot T, Stanisiere JY, Bocquene G, Menard D, Minier C et al. Seasonal variations of a battery of biomarkers and physiological indices for the mussel Mytilus galloprovincialis transplant into the northwest Mediterranean Sea. Comp Biochem Physiol 2004; 138C:411-27.

Borg D, Schaich K. Cytotoxicity from coupled redox cycling of autoxidizing xenobiotics and metals. Israel J Chem 1983; 24:38-53.

Cajaraville MP, Bebianno MJ, Blasco J, Porte C, Sarasquete C, Viarengo A. The use of biomarkers to assess the impact of pollution in coastal environments of the Iberian Peninsula: A practical approach. Sci Total Environ 2000; 247:295-311.

Cheney D, MacDonald B, Elston R. Summer mortality of Pacific oysters, Crassostrea gigas (Thunberg): initial findings on multiple environmental stressors in Puget Sound, Washington. J Shellfish Res 2000; 19:353-9.

Clark RB. The Long-Term Effect of Oil Pollution on Marine Populations, Communities and Ecosystems: Some Questions. Phil Trans R Soc Lond B 1982; 297:185-192.

Damasio J, Navarro-Ortega A, Tauler R, Lacorte S, Barceló D, Soares AM, López MA, Riva MC, Barata C. Identifying major pesticides affecting bivalve species exposed to agricultural pollution using multibiomarker and multivariate methods. Ecotoxicology 2010; 19:1084-94. 
Davies IM, Vethaak AD. Integrated marine environmental monitoringof chemicals and their effects. ICES Cooperative Research Report No. 315; 2012.

De La Parra A, Garcia O, San Juan F. Seasonal variations on the biochemical composition and lipid classes of the gonadal and storage tissues of Crassostrea gigas (Thunberg, 1794) in relation to the gametogenic cycle. J Shellfish Res 2005; 24:457-67.

Di Giulio RT, Washburn PC, Wenning RJ, Winston GW, Jewell CS. Biochemical responses in aquatic animals: A review of determinants of oxidative stress. Environ Toxicol 1989; 8:1103-23.

Dubois M, Gilles KA, Hamilton JK, Rebers PA, Smith F. Colorimetric method for determination of sugars and related substances. Anal Chem 1956; 28:350-6.

Eggert C, Temp U, Eriksson K. The ligninolytic system of the white rot fungus Pycnoporus cinnabarinus: purification and characterisation of the laccase. App Environ Microb 1996; 62:1151-8.

Espin J, Morales M, Varon R, Tudela J, Garcia-Canovas F. A continuous spectrophotometric method for determining the monophenolase and diphenolase activites of apple polyphenol oxidase. Anal Biochem $1995 ; 231: 237-46$.

FAO. Aquaculture Production: Quantities 1950-2008. Fishstat Plus; 2010.

Folch J, Lees M, Sloane Stanley H. A simple method for the isolation and purification of total lipids from animal tissues. J Biol Chem 1956; 226:497-509.

Fossati P, Prencipe L, Berti G. Use of 3,5-dichloro-2-hydroxibenzenesulfonic acid/4-aminophenazone chromogenic system in direct enzymic assay of uric acid in serum and urine. Clin Chem 1980; 26:22731.

Gabbott P. Storage cycles in marine bivalve molluscs: a hypothesis concerning the relationship between glycogen metabolism and gametogenesis. In: Barnes HB, editor. European Marine Biology Symposia, Aberdeen; 1975. 
Gabbott PA, Head EJH. Seasonal changes in the specific activities of the pentose phosphate pathway enzymes, G6PDH and 6PGDH and NADP-dependent isocitrate dehydrogenase in the bivalves Mytilus edulis, Ostrea edulis and Crassostrea gigas. Comp Biochem Physiol 1980; 66B:279-84.

Galgani F, Martinez-Gomez C, Giovinardi F, Romanelli G, Caixach J, Cento A. Assessment of polycyclic aromatic hydrocarbon concentrations in mussels (Mytilus galloprovincialis) from the Western basin of the Mediterranean Sea. Environ Monit Assess 2011; 172:301-317.

Garnier M, Labreuche Y, Garcia C, Robert M, Nicolas JL. Evidence for the involvement of pathogenic bacteria in summer mortalities of the Pacific oyster Crassostrea gigas. Microb Ecol 2007; 53:187-96.

Gauthier-Clerc S, Pellerin J, Blaise C, Gagne F. Delayed gametogenesis of Mya arenaria in the Saguenay fjord (Canada): a consequence of endocrine disruptors? Comp Biochem Physiol 2002; 131C:457-67.

Geffard A, Amiard JC, Amiard-Triquet C. Kinetics of metal elimination in oysters from a contaminated estuary. Comp Biochem Physiol 2002; 131C:281-93.

Gerard-Monnier D, Erdelmeier I, Regnard K, Moze-Henry N, Yadan J, Chaudiere J. Reactions of 1methyl-2-phenylindole with malondialdehyde and 4-hydroxyalkenals. Analytical applications to a colorimetric assay of lipid peroxidation. Chem Res Toxicol 1998; 11:1176-83.

Greenfield R, Brink K, Degger N, Wepener V. The usefulness of transplantation studies in monitoring of metals in the marine environment: South African experience. Mar Poll Bull 2014; 30:566-73.

Guidi P, Frenzilli G, Benedetti M, Bernardeschi M, Falleni A, Fattorini D, Regoli F, Scarcelli V, Nigro M. Antioxidant, genotoxic and lysosomal biomarkers in the freshwater bivalve (Unio pictorum) transplanted in a metal polluted river basin. Aquat Toxicol 2010; 100:75-83.

Gunther AJ, Davis JA, Hardin DD, Gold J, Bel D. Long-term bioaccumulation monitoring with transplanted bivalves in the San Francisco Estuary. Mar Poll Bull 1999; 38:170-181.

Gutierrez JL, Jones CG, Strayer DL, Iribarne OO. Mollusks as ecosystem engineers: the role of shell production in aquatic habitats. Oikos 2003; 79-90. 
Hagger JA, Depledge MH, Galloway TS. Toxicity of tributyltin in the marine mollusc Mytilus edulis. Mar Poll Bull 2005; 51:811-6.

Hédouin L, Pringault O, Bustamante P, Fichez R, Warnau M. Validation of two tropical marine bivalves as bioindicators of mining contamination in the New Caledonia lagoon: field transplantation experiments. Water Res 2011; 45:483-96.

Hyötylänen T, Karels A, Oikari A. Assessment of bioavailability and effects of chemicals due to remediation actions with caging mussels (Anodonta anatina) at a creosote-contaminated lake sediment site. Water Res 2002; 36:4497-504.

Krishnakumar PK, Casillas E, Varanasi U. Effects of chemical contaminants on the health of Mytilus edulis from Puget Sound, Washington. II. Cytochemical detection of subcellular changes in digestive cells. Mar Biol 1995; 124:251-9.

Lacoste A, Jalabert F, Malham SK, Cueff A, Poulet SA. Stress and stress-induced neuroendocrine changes increase the susceptibility of juvenile oysters (Crassostrea gigas) to Vibrio splendidus. Gen Comp Endocrinol 2001: 67:2304-9.

Lagadic L, Caquet T, Ramade F. The role of biomarkers in environmental assessment (5). Invertebrate populations and communities. Ecotoxicology 1994; 3:193-208.

Laroche J, Gauthier O, Quiniou L, Devaux A, Bony S, Evrard E et al. Variation patthers in individual fish responses to chemical stress among estuaries, seasons and genders: the case of the European flounder (Patichthys flesus) in the Bay of Biscay. Environmental Science and Pollution Research 2013; 2:738748.

Leps JS, Smilauer P. Multivariate analysis of ecological data: course material. Ceske Budejovice; 1999.

Livingstone D. Biotechnology and pollution monitoring: Use of molecular biomarkers in the aquatic environment. J Chem Technol Biotechnol 1993; 57:195-211.

Lobel P, Wright D. Relationship between body zinc concentration and allometric growth measurements in the mussel Mytilus edulis. Mar Biol 1982; 66:145-50. 
Luna-Acosta A, Bustamante P, Godefroy J, Fruitier-Arnaudin I, Thomas-Guyon H. Seasonal variation of pollution biomarkers to assess the impact on health status of juvenile Pacific oysters Crassostrea gigas exposed in situ. Environ Sci Poll Res 2010a; 17:999-1008.

Luna-Acosta A, Rosenfeld E, Amari M, Fruitier-Arnaudin I, Bustamante P, Thomas-Guyon H. First evidence of laccase activity in the Pacific oyster Crassostrea gigas. Fish Shellfish Immunol 2010b; 28:719-26.

Luna-Acosta A, Kanan R, Le Floch S, Huet V, Pineau P. Bustamante P, Thomas-Guyon H. Enhanced immunological and detoxification responses in Pacific oysters, Crassostrea gigas, exposed to chemically dispersed oil. Water Res 2011a; 14:4103-18.

Luna-Acosta A, Thomas-Guyon H, Amari M, Rosenfeld E, Bustamante P, Fruitier-Arnaudin I. Differential tissue distribution and specificity of phenoloxidases from the Pacific oyster Crassostrea gigas. Comp Physio Biochem 2011b; 159B(4):220-6.

Luna-Acosta A, Renault T, Thomas-Guyon H, Faury N, Saulnier D, Budzinski H, Le Menach K, Pardon P, Fruitier-Arnaudin I, Bustamante P. Detection of early effects of a single herbicide (diuron) and a mix of herbicides and pharmaceuticals (diuron, isoproturon, iburpofen) on immunological parameters of Pacific oyster (Crassostrea gigas) spat. Chemosphere 2012: 87:1335-40.

Magni P, De Falco G, Falugi C, Franzoni M, Monteverde M, Perrone E, Sgro M, Bolognesi C. Genotoxicity biomarkers and acetylcholinesterase activity in natural populations of Mytilus galloprovincialis along a pollution gradient in the Gulf of Oristano (Sardinia, wester Mediterranean). Env Poll 2006; 142:65-72. 
Manduzio H, Monsinjon T, Galap C, Leboulenger F, Rocher B. Seasonal variations in antioxidant defences in blue musselsMytilus edulis collected from a polluted area: major contributions in gills of an inducible isoform of $\mathrm{Cu} / \mathrm{Zn}$-superoxide dismutase and of glutathione $S$-transferase. Aquat Tox 2004; 70:83-93.

Miramand P, Guyot T, Pigeot J Sources et impacts potentiels des micropolluants chimiques sur un écosystème littoral exploité: L'exemple des côtes de Charente-Maritime. J Phy IV (Proceedings) 2003; 108:3-6.

Mourgaud Y, Martinez E, Geffard A, Andral B, Stanisiere J-Y, Amiard J-C. Metallothionein concentration in the mussel Mytilus galloprovincialis as a biomarker of response to metal contamination: validation in the field. Biomarkers 2002; 7:479-90.

Munaron D, Dubernet J, Delmas F, Stanisiere J, Scribe P. Assessment of the quantities of herbicides and nutrients brought down by the river Charente to the coast and modelling of the dispersion of atrazine in the Marennes-Oléron bay. Cah Biol Mar 2006; 47:85-92.

Neumann N, Stafford J, Barreda D, Ainsworth A, Belosevic M. Antimicrobial mechanisms of fish phagocytes and their role in host defense. Dev Comp Immunol 2001; 25:807-25.

Oliver LM, Fisher WM. Comparative form and function of oyster Crassostrea virginica hemocytes from Chesapeake Bay (Virginia) and Apalachicola Bay (Florida). Dis Aquat Org 1995; 22:217-25.

Orbea A, Cajaraville M. Peroxisome proliferation and antioxidant enzymes in transplanted mussels of four basque estuaries with different levels of polycyclic aromatic hydrocarbon and polychlorinated biphenyl pollution. Environ Toxicol Chem 2006; 25:1616-26.

Orbea A, Ortiz-Zarragoitia M, Sole M, Porte C, Cajaraville MP. Antioxidant enzymes and peroxisome proliferation in relation to contaminant body burdens of PAHs and PCBs in bivalve molluscs, crabs and fish from the Urdaibai and Plentzia estuaries (Bay of Biscay). Aquat Toxicol 2002; 58:75-98.

Packard GC, Boardman TJ. The use of percentages and size-specific indices to normalize physiological data for variation of body size: wasted time, wasted effort? Comp Biochem Physiol 1999; 122A:37-44. 
Paglia D, Valentine W. Studies on the quantitative and qualitative characterisation of erythrocyte glutathione peroxidase. J Lab Clin Med 1967; 70:158-69.

Pellerin-Massicotte J, Martineu P, Desrosiers G, Caron A, Scaps P. Seasonal variability in biochemical composition of the polychaete Nereis virens (Sars) in two tidal flats with different geographic orientations. Comp Biochem Physiol 1994; 107A:509-16.

Perdue J, Beattie J, Chew K. Some relationships between gametogenic cycle and summer mortality phenomenon in the Pacific oyster (Crassostrea gigas) in Washington State. J Shellfish Res 1981; 1:916.

Porte C, Sole M, Albaiges J, Livingstone DR. Responses of mixed-function oxigenase and antioxidase enzyme system of Mytilus sp. to organic pollution. Comp Biochem Physiol C 1991; 100C:183-6.

Pigeot J, Miramand P, Guyot T, Sauriau PG, Fichet D, Le Moine O, Huet V. Cadmium pathways in an exploited intertidal ecosystem with chronic cadmium inputs (Marennes-Oléron, Atlantic coast, France). Mar Ecol Prog Ser 2006; 307:101-14.

Richardson BJ, Mak E, De Luca-Abbott SB, Martin M, McClellan K, Lam PKS. Antioxidant responses to polycyclic aromatic hydrocarbons and organochlorine pesticides in green-lipped mussels (Perna viridis): Do mussels "integrate" biomarker responses? Mar Poll Bull 2008; 57:503-14.

Rodriguez-Ariza A, Martínez-Lara E, Pascual P, Pedrajas JR, Abril N, Dorado G, Toribio F, Barcena JA,

Ross K, Cooper N, Bidwell J, Elder J. Genetic diversity and metal tolerance of two marine species: A comparison between populations from contaminated and reference sites. Mar Poll Bull 2002; 44:671-9.

Samain JF, Dégremont L, Soletchnik P, Haure J, Bédier E, Ropert M et al. Genetically based resistance to summer mortality in the Pacific oyster (Crassostrea gigas) and its relationship with physiological, immunological characteristics and infection processes. Aquaculture 2007; 268:227-243.

Smith P, Krohn R, Hermanson G, Mallia A, Gartner F, Provenzano M et al. Measurement of protein using bicinchoninic acid. Anal Biochem 1985; 150:76-85. 
Sole M, Porte C, Albaiges J. The use of biomarkers for assessing the effects of organic pollution in mussels. Sci Total Environ 1995; 159:147-53.

Soletchnik P, Faury N, Goulletquer P. Seasonal changes in carbohydrate metabolism and its relationship with summer mortality of Pacific oyster Crassostrea gigas (Thunberg) in Marennes-Oléron bay (France). Aquaculture 2006; 252:328-38.

Soletchnik P, Le Moine O, Faury N, Razet D, Geairon P, Goulletquer P. Mortalité de l'huître Crassostrea gigas dans le bassin de Marennes-Oléron: étude sur la variabilité spatiale de son environnement et de sa biologie par le systeme d'informations geographiques (SIG). Aquat Living Res 1999; 12:131-43.

Soudant P, Paillard C, Choquet G, Lambert C, Reid H, Marhic A et al. Impact of season and rearing site on the physiological and immunological parameters of the Manila clam Venerupis (=Tapes, =Ruditapes) philippinarum. Aquaculture 2004; 229:401-18.

Strady E, Blanc G, Baudrimont M, Schäfer J, Robert S, Lafon V. Roles of regional hydrodynamic and trophic contamination in cadmium bioaccumulation by Pacific oysters in the Marennes-Oléron Bay (France). Chemosphere 2011; 84:80-90.

Tapie N, Budzinski H, Le Menach K. Fast and efficient extraction methods for the analysis of polychlorinated biphenyls and polybrominated diphenyl ethers in biological matrices. Anal Bioanal Chem 2008; 391:2169-77.

Therond P, Gerbaud P, Dimon S, Anderson WB, Evain-Brion D, Raynaud F. Antioxidant enzymes in psoriatic fibroblasts and erythrocytes. J Investigative Dermatol 1996; 106:1325-31.

Thompson S, Budzinski H. Determination of polychlorinated biphenyls and chlorinated pesticides in environmental biological samples using focused microwave-assisted extraction. Int J Envir Anal Chem 2000; 76:49-60.

Winston GW. Oxidants and antioxidants in aquatic animals. Comp Biochem Physiol 1991; 100C:173-176 Zar J. Biostatistical analysis. 2d ed. New Jersey: Prentice-Hall; 1984. 


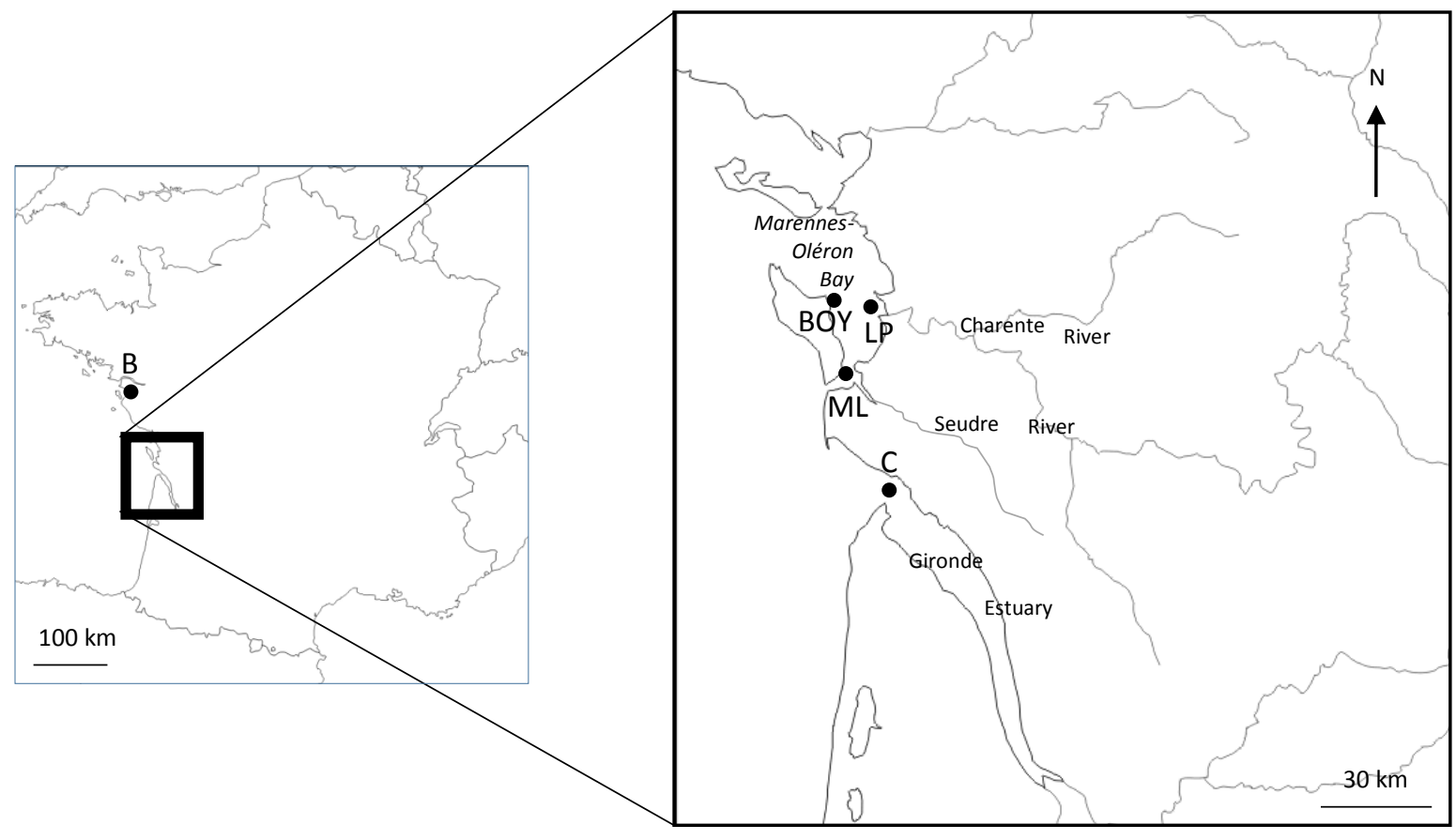

Figure 1. Estuarine sampling areas in French Atlantic coast. Location of reference (B, Bouin) and transplantation sites: Boyard (BOY), Les Palles (LP), Mus du Loup (ML) in the Marennes-Oléron Bay and Cordouan (C) in the Gironde Estuary. 
a

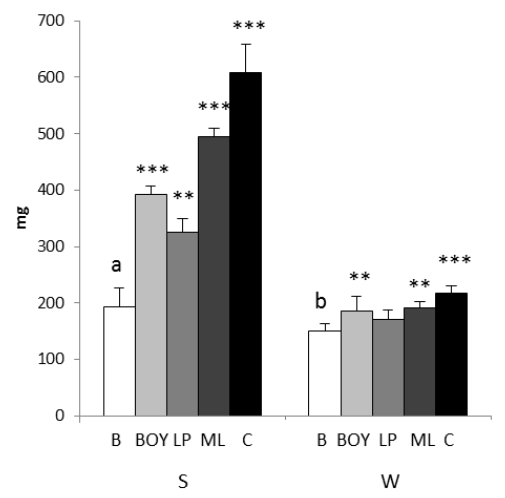

b

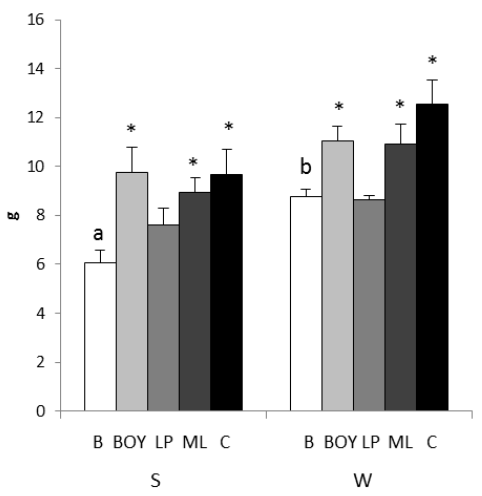

C

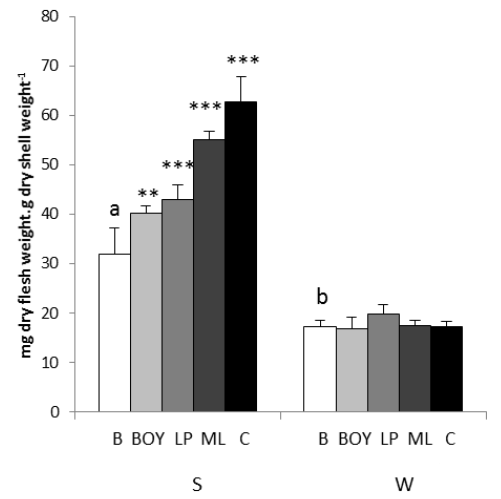

Figure 2. Flesh dry weight (a), shell dry weight (b) and condition index (c) in C. gigas from reference site (Bouin white bars, B), and transplantation sites (Boyard -light grey bars, BOY-, Les Palles -medium grey bars, LP-, Mus du Loup -dark grey bars, ML- and Cordouan -black bars, C-), in summer (S) and in winter (W). Data are expressed as mean \pm SD. For clarity of results, only significant differences between reference and transplantation sites are shown; $* \mathrm{p}<0.05, * *<\mathrm{p} 0.01, * * * \mathrm{p}<0.001$. Superscript letters indicate significant $(\mathrm{p}<0.05)$ differences between B samples from summer and winter. 


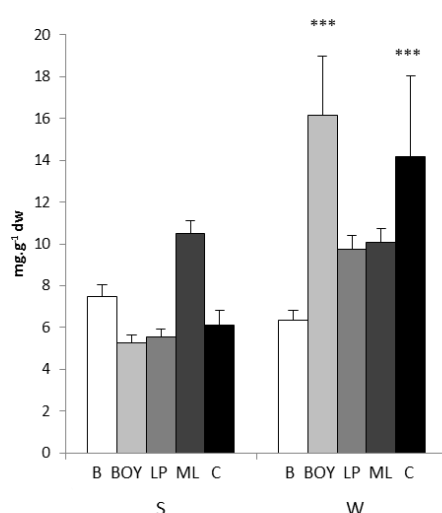

b

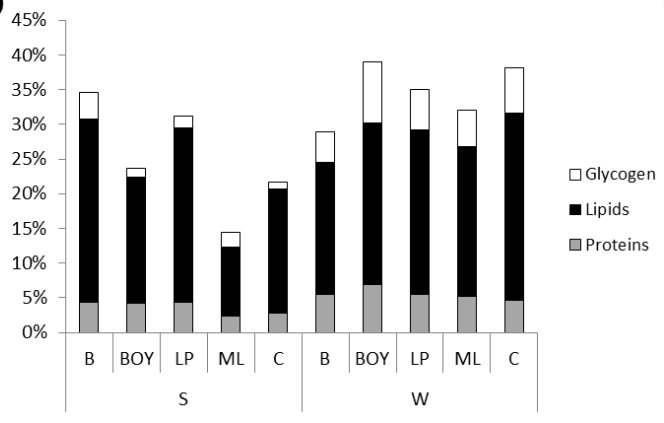

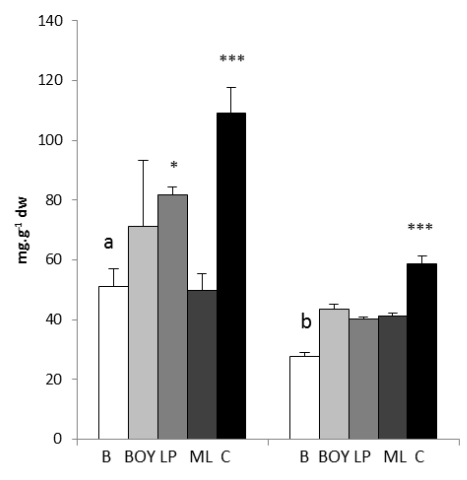

W

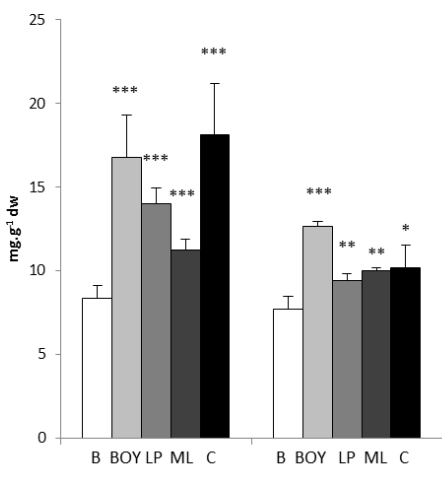

$\mathrm{S}$

C ${ }_{100 \%}$

Figure 3. Energy reserves (glycogen, lipids, proteins) in the digestive gland of $C$. gigas. a. Energy reserves from reference site (Bouin, white bars), and transplantation sites (Boyard -light grey bars-, Les Palles -medium grey bars-, Mus du Loup -dark grey bars- and Cordouan -black bars-), in summer (S) and in winter (W). Data are expressed as mean \pm SD. For clarity of results, only significant differences between reference and transplant sites are shown; * $\mathrm{p}<0.05, * *<\mathrm{p} 0.01, * * * \mathrm{p}<0.001$. Superscript letters indicate significant $(\mathrm{p}<0.05)$ differences between B samples from summer and winter. b. Levels of energy reserves (glycogen in white, lipids in black, proteins in grey) are expressed in percentage (\%) relative to the total flesh dry weight. c. Levels of energy reserves (glycogen in white, lipids in black, proteins in grey) are presented in percentage (\%) relative to the total fresh dry weight, with the total fresh dry weight standardized for all sites and seasons to 100\%. B: Bouin, BOY: Boyard, LP: Les Palles, ML: Mus du Loup, C: Cordouan, S: Summer, W: Winter. 

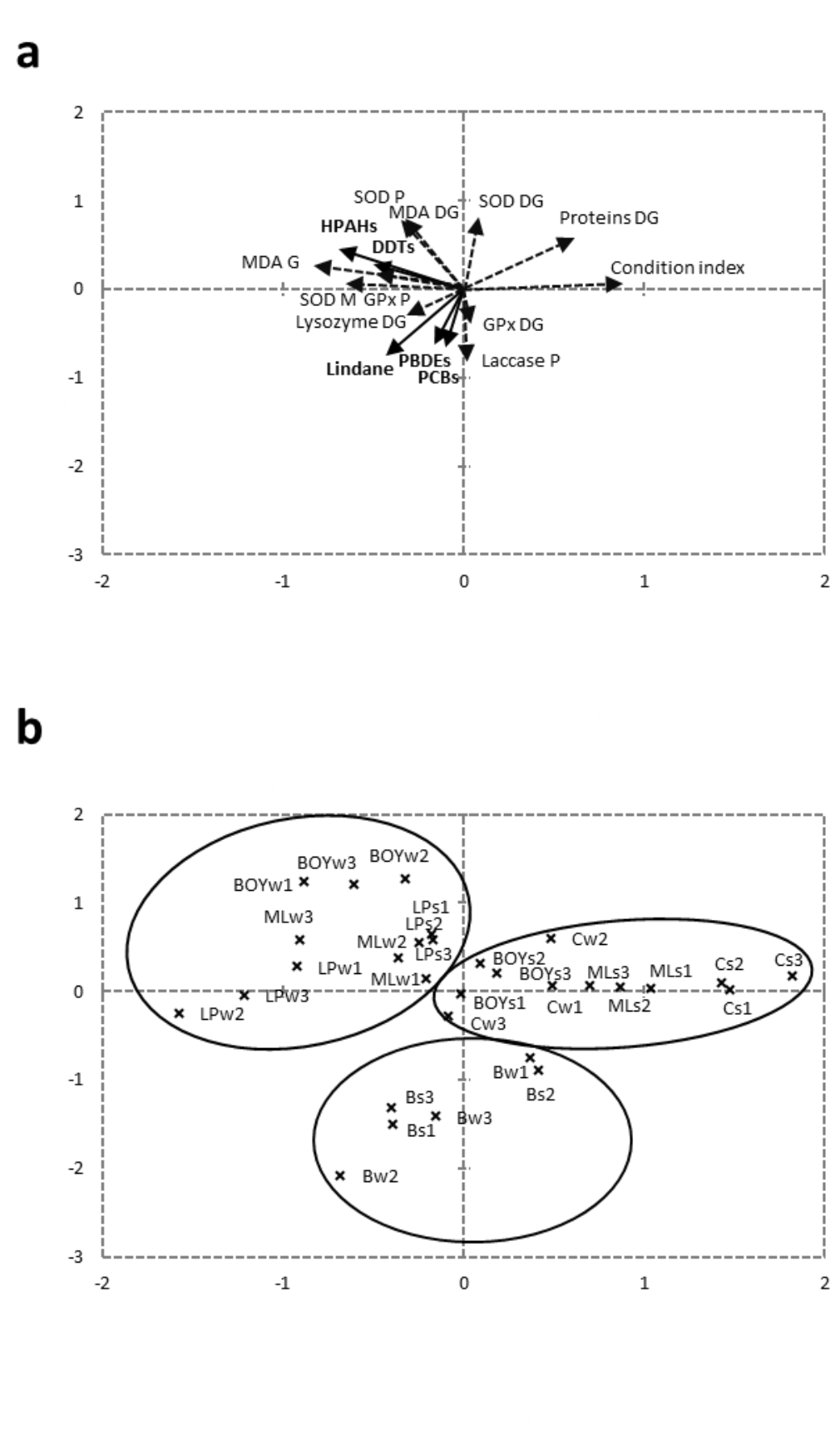

Figure 4. Redundancy analysis (RDA) ordination diagram with (a) contaminant contents (straight arrows), and biochemical parameters (dotted arrows) and (b) sampling sites. First axis is horizontal, second axis is vertical. The first axis displays $42 \%$ of the remaingroupng variation in contaminants in oysters, the second axis another $35 \%$. Only biomarkers that significantly $(\mathrm{p}<0.05)$ contributed to discriminate sites depending on their degree of contamination were used to carry out the RDA analysis. HPAHs: heavy polycyclic aromatic hydrocarbons; PCBs: polychlorobiphenyls; PBDEs: polybromodimethylethers; DDTs: dichlorodiphenyltrichloroethanes, dichlorodiphenyldichloroethanes and dichlorodiphenyldichloroethylenes; SOD: superoxide dismutase; GPx: glutathione peroxidase; MDA : malondialdehyde; G : gills ; DG : digestive gland ; M : mantle ; P : plasma; B: Bouin; BOY: Boyard; LP: Les Palles; ML: Mus du Loup; C: Cordouan; s: summer; w: winter; 1: replicate 1; 2: replicate 2; 3: replicate 3 . 
Table 1. Contaminant contents in oyster's flesh at two seasons after 3 months of transplantation. Mean $\pm \mathrm{SD}\left(\mu \mathrm{kg} \mathrm{kg}^{-1} \mathrm{dw}\right), n=3$ (i.e. 3 replicates from 1 pool of 5 oysters). B: Bouin; BOY: Boyard; LP: Les Palles; ML: Mus du Loup; C: Cordouan; dw: dry weight; nd: not detected. PAHs: polycyclic aromatic hydrocarbons; LPAHs: low molecular weight PAHs; HPAHs: high molecular weight PAHs; PCBs: polychlorobiphenyls; PBDEs: polybromodimethylethers; DDTs (DDT and metabolites: dichlorodiphenyltrichloroethanes (2,4'-DDT and 4,4'-DDT) + dichlorodiphenyldichloroethylenes (2,4'-DDE and 4,4'-DDE) + dichlorodiphenyldichloroethanes (2,4'-DDD and 4,4’-DDD)); HCB: hexachlorobenzene; HC: heptachlor; TNC: trans-nonachlor.

\begin{tabular}{|c|c|c|c|c|c|c|c|c|c|c|}
\hline \multirow{3}{*}{ Contaminants } & \multicolumn{10}{|c|}{ Concentration $\left(\mu \mathrm{g} \mathrm{kg}^{-1} \mathrm{dw}\right)$} \\
\hline & \multicolumn{5}{|c|}{ Summer } & \multicolumn{5}{|c|}{ Winter } \\
\hline & B & BOY & $\mathbf{L P}$ & ML & C & B & BOY & $\mathbf{L P}$ & ML & $\mathbf{C}$ \\
\hline LPAHs & $68 \pm 6$ & $58 \pm 9$ & $47 \pm 14$ & $27 \pm 1$ & $45 \pm 25$ & $69 \pm 16$ & $68 \pm 19$ & $60 \pm 12$ & $41 \pm 5$ & $44 \pm 5$ \\
\hline HPAHs & $60 \pm 1$ & $81 \pm 10$ & $141 \pm 11$ & $54 \pm 10$ & $35 \pm 7$ & $87 \pm 10$ & $167 \pm 25$ & $145 \pm 3$ & $159 \pm 34$ & $76 \pm 12$ \\
\hline PCBs & $81 \pm 9$ & $30 \pm 3$ & $23 \pm 4$ & $15 \pm 1$ & $39 \pm 12$ & $89 \pm 39$ & $47 \pm 3$ & $30 \pm 3$ & $17 \pm 6$ & $44 \pm 4$ \\
\hline PBDEs & $0.9 \pm 0.0$ & $0.4 \pm 0.4$ & $0.4 \pm 0.3$ & $0.4 \pm 0.0$ & $0.9 \pm 0.2$ & $2.9 \pm 0.7$ & $0.6 \pm 0.3$ & $1.0 \pm 0.7$ & $0.6 \pm 0.1$ & $0.5 \pm 0.1$ \\
\hline DDTs & $6 \pm 1$ & $8 \pm 1$ & $6 \pm 1$ & $2 \pm 0$ & $3 \pm 0$ & $6 \pm 3$ & $15 \pm 0$ & $10 \pm 1$ & $4 \pm 0$ & $8 \pm 2$ \\
\hline Lindane & $2.1 \pm 0.4$ & $0.6 \pm 0.1$ & $0.4 \pm 0.0$ & $0.1 \pm 0.1$ & $0.1 \pm 0.0$ & $2.2 \pm 1.1$ & $0.5 \pm 0.2$ & $1.3 \pm 0.3$ & $0.6 \pm 0.1$ & $0.7 \pm 0.4$ \\
\hline $\mathrm{HCB}+\mathrm{HC}+\mathrm{TNC}$ & $2.2 \pm 0.4$ & $2.4 \pm 0.9$ & $2.0 \pm 0.3$ & $0.8 \pm 0.0$ & $0.8 \pm 0.0$ & $1.8 \pm 0.8$ & $3.5 \pm 1.0$ & $4.1 \pm 1.9$ & $0.7 \pm 0.0$ & $1.9 \pm 0.1$ \\
\hline
\end{tabular}




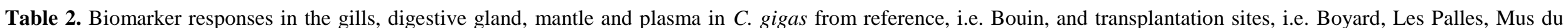

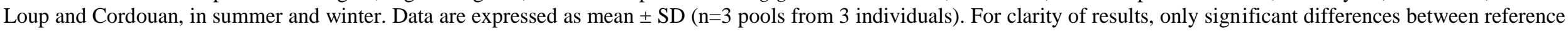
and transplantation sites are shown; $* \mathrm{p}<0.05$, **< 0.01 , *** $\mathrm{p}<0.001$.

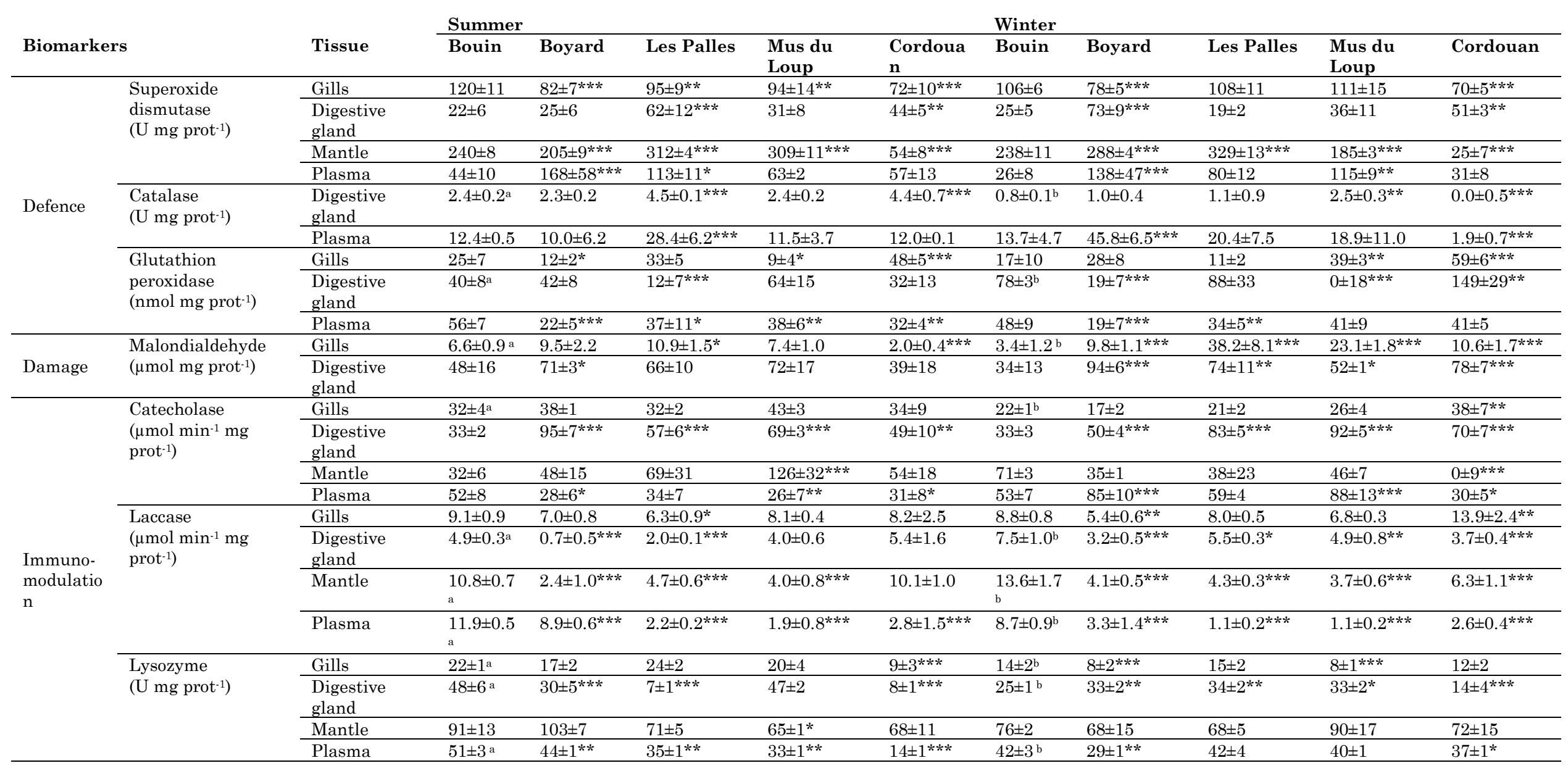


Table 3. Physico-chemical and biological parameters of the reference (Bouin, B) and the transplantion sites (Boyard, BOY; Les Palles, LP; Mus du Loup, ML; Cordouan: C) in summer (June) and winter (December), 2008.

\begin{tabular}{|c|c|c|c|c|c|c|c|c|c|c|}
\hline & \multicolumn{5}{|l|}{ Summer } & \multicolumn{5}{|l|}{ Winter } \\
\hline & B & BOY & LP & ML & C & B & BOY & LP & ML & C \\
\hline \multicolumn{11}{|l|}{ Physicochemical parameters } \\
\hline Temperature $\left({ }^{\circ} \mathrm{C}\right)^{\mathrm{a}}$ & $18 \pm 2$ & $19 \pm 2$ & $20 \pm 2$ & $20 \pm 2$ & $21 \pm 2$ & $9 \pm 2$ & $9 \pm 2$ & $8 \pm 2$ & $10 \pm 3$ & $8 \pm 3$ \\
\hline Salinitya & $33 \pm 1$ & $33 \pm 1$ & $33 \pm 1$ & $33 \pm 1$ & $33 \pm 2$ & $31 \pm 2$ & $32 \pm 2$ & $31 \pm 3$ & $30 \pm 3$ & $32 \pm 3$ \\
\hline Turbidity (NTU)a & $4 \pm 5$ & $6 \pm 4$ & $4 \pm 1$ & $10 \pm 8$ & $4 \pm 6$ & $34 \pm 27$ & $22 \pm 11$ & $12 \pm 8$ & $14 \pm 12$ & $10 \pm 11$ \\
\hline \multicolumn{11}{|l|}{ Biological parameters } \\
\hline \multicolumn{10}{|l|}{ Phytoplancton (cells $\left.\mathrm{I}^{-1}\right)^{\mathrm{a}}$} & $1.2^{\mathrm{a}}$ \\
\hline Cryptophyceae (Cryptophyceae) & $10^{5-6}$ & - & - & - & - & - & - & - & - & - \\
\hline Asterionellopsis glacialis (Diatomophyceae) & $10^{5-6}$ & - & - & - & - & - & - & - & - & - \\
\hline Chaetoceros sp.(Diatomophyceae) & $10^{5-6}$ & $10^{5-6}$ & $10^{5-6}$ & $10^{5-6}$ & $10^{5-6}$ & - & $10^{3-4}$ & $10^{3-4}$ & $10^{3-4}$ & - \\
\hline Cylindrotecha closterium (Diatomophyceae) & - & & - & - & - & $10^{3-4}$ & $10^{3-4}$ & $10^{3-4}$ & $10^{3-4}$ & - \\
\hline Guinardia delicatula (Diatomophyceae) & - & - & - & - & $10^{5-6}$ & - & - & - & - & - \\
\hline Leptocylindrus sp. (Diatomophyceae) & $10^{5-6}$ & $10^{5-6}$ & $10^{5-6}$ & $10^{5-6}$ & $10^{5-6}$ & - & - & - & - & - \\
\hline Nitzchia longissima (Diatomophyceae) & $10^{5-6}$ & $10^{5-6}$ & $10^{5-6}$ & $10^{5-6}$ & $10^{5-6}$ & - & - & - & - & $10^{3-4}$ \\
\hline Paralia sulcata (Diatomophyceae) & - & $10^{5-6}$ & $10^{5-6}$ & $10^{5-6}$ & $10^{3-4}$ & - & $10^{3-4}$ & $10^{3-4}$ & $10^{3-4}$ & $10^{5-6}$ \\
\hline Skeletonema costatum (Diatomophyceae) & $10^{5-6}$ & - & - & - & $10^{5-6}$ & $10^{3-4}$ & $<10^{3}$ & $<10^{3}$ & $<10^{3}$ & - \\
\hline Thalassiosira sp. (Diatomophyceae) & - & - & - & - & $10^{5-6}$ & $10^{3-4}$ & - & - & - & - \\
\hline Gymonodiniaceae (Dinophyceae) & - & - & - & - & $10^{5-6}$ & - & - & - & - & - \\
\hline Phytoplancton producing phycotoxins (cells $\mathrm{I}^{-1}$ ) a & & & & & - & & & & & \\
\hline Alexandrium sp. (Diatomophyceae) & $\leq 10^{2}$ & $\leq 10^{1}$ & $\leq 10^{1}$ & $\leq 10^{1}$ & $10^{3-4}$ & $\leq 10^{1}$ & $\leq 10^{1}$ & $\leq 10^{1}$ & $\leq 10^{1}$ & $\leq 10^{2}$ \\
\hline Dinophysis sp. (Dinophyceae) & $\leq 10^{2}$ & $\leq 10^{2}$ & $\leq 10^{1}$ & $\leq 10^{1}$ & $\leq 10^{1}$ & $\leq 10^{1}$ & $\leq 10^{1}$ & $\leq 10^{1}$ & $\leq 10^{1}$ & $\leq 10^{1}$ \\
\hline Pseudo-nitzchia sp. (Diatomophyceae) & $\leq 10^{4}$ & $\leq 10^{3}$ & $\leq 10^{2}$ & $\leq 10^{2}$ & $\leq 10^{4}$ & $\leq 10^{1}$ & $\leq 10^{2}$ & $\leq 10^{1}$ & $\leq 10^{1}$ & $\leq 10^{1}$ \\
\hline \multicolumn{11}{|l|}{ Phycotoxins ${ }^{\mathrm{a}}$} \\
\hline Amnesic shellfish poisoning (ASP) & - & - & - & - & - & - & - & - & - & - \\
\hline Diarrheic shellfish poisoning (DSP) & - & - & - & - & - & - & - & - & - & - \\
\hline Paralytic shellfish poisoning (PSP) & - & - & - & - & - & - & - & - & - & - \\
\hline Fecal contamination (E.coli $\left.100^{-1} \mathrm{~g}^{-1} \mathrm{ILC}\right)^{\text {a }}$ & $<230$ & $<230$ & $<230$ & $<230$ to 4600 & $<230$ & $<230$ & $<230$ & $<230$ & $<230$ & $<230$ \\
\hline
\end{tabular}

\section{“-“: not detected}

ILC: intervalvular liquid content

a Mean values \pm SD adapted from 2000 to 2006 data of the website "Site Ifremer consacré à l'environnement littoral": http://www.ifremer.fr/envlit/.

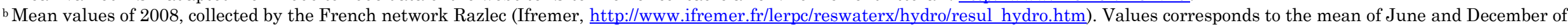

2008 of two measurements carried out per month at the bottom and at the top of the water surface from ML and sites near BOY and LP 